УДК 378.147

DOI: $10.24144 / 2524-0609.2021 .49 .47-50$

\author{
Humeniuk Vasyl \\ $\mathrm{PhD}$ in Pedagogical Sciences, Associate Professor \\ Associate Professor of the Catastrophe Medicine and Military Medicine Department \\ Danylo Halytsky Lviv National Medical University, Lviv, Ukraine \\ basilleo03@gmail.com \\ http://orcid.org/0000-0003-2736-3875
}

\title{
PEDAGOGICAL CONDITIONS OF TRAINING FUTURE MASTERS OF MEDICINE FOR PEDAGOGICAL ACTIVITY IN HIGHER MEDICAL INSTITUTIONS OF EDUCATION
}

\begin{abstract}
The training of future masters of medicine for teaching is extremely important. On the shoulders of doctors rests the responsibility for people's lives, for the future of the nation. The modern doctor, interacting with patients and colleagues, should take the position of not only a physician, but also the position of a teacher, educator, assistant, friend, and mentor. Pedagogy helps to form, develop and implement all these qualities. Knowledge in the field of pedagogy helps a doctor to become a worthy profession representative, easy to communicate with varous group of population, while demonstrating high professionalism and generosity. The aim of the study is to reflect the pedagogical conditions of training of future masters of medicine for teaching in higher medical educational institutions. Research methods applied: system analysis, logical and theoretical generalization, grouping and comparison. It has been established that pedagogical conditions provide the creation of an educational environment for the training of future masters of medicine in higher medical educational institutions. By pedagogical conditions of training the future masters of medicine for pedagogical activity in higher medical educational institutions is understood: (i) the orientation of the educational process on the formation of motivational and value attitude of future masters of medicine to pedagogical activity in the health care system; (ii) pedagogically oriented connotation of the content and methods of studying the general scientific and medical disciplines; (iii) optimal combination of educational forms, methods, technologies in the obtaining by future masters of medicine the pedagogical component in medical practice; (iv) stimulating the future masters of medicine to personal and professional self-development.
\end{abstract}

Key words: higher medical educational institutions; future masters of medicine; pedagogical activity in health care; pedagogical conditions; vocational training system.

Introduction. The training of future masters of medicine (MMed) in higher medical educational institutions (HMEIs) is currently not perfect enough from the perspectives of modern cultural and value positions. It does not provide a proper scientific basis for the practice of university education. Productive solution of problems of training of future MMed for pedagogical activity in the health care system, comprehensive development of necessary social qualities of future specialists is possible on the basis of analysis of educational and organizational work, generalization of conclusions of theoretical and exact sociological researches at the border of medicine, pedagogy of higher medcial school, theory of a personality and culture, pedagogical heritage of medical practice, etc. The fundamental difference between the concept of the modern paradigm of education of HMEI is that the system of higher medical education is seen as an activity aimed at the development of intellectual and moral personality in order to preserve human life and optimize the quality of medical care for patients. We consider the system-value approach in training of medical students for pedagogical activity as the system constructed taking into account cultural and humanistic values of new century: subjectivity, dialogicity, developmental orientation, integration, fundamentality and continuity.

Analysis of recent research and publications. Analysis of scientific literature on the problem under research shows that domestic and foreign scholars have performed a number of studies on the pedagogical orientation of professional activity of health care system professionals. Thus, the psychological and pedagogical issues of personality development of future physicians are studied in the publications of I. Balyakova, M. Muravyova, L. Ostrovska, N. Pakhomova et al. Some issues of pedagogical training of physicians in educating patients have been revealed by I. Glinkina, V. Osypova, T. Pertseva, I. Tarasova et al. The training of a doctorteacher in scientific research is highlighted in details in the works of M. Kamilov, N. Kudryava, L. Lonska, O. Lopanova, I. Novgorodtseva, S. Noskova. Also in this regard, S. Bukhalska's works are of some interest, in which the author reveals a modern approach to pedagogical medicine, its goals, conceptual framework, and methodology [1]. A. Yemets' researches aim at studying the role of patient education in the professional activity of a doctor [2]. Numerous studies performed by Western European scholars are aimed at studying the issues of population health promotion and health education. Such a significant attention, paid to scientific researches of pedagogical aspects of professional activity of medical workers, is caused by: the process of integration of treatment and education of patients and their relatives; the necessity to form a readiness to maintain and improve health, healthy lifestyle in broad sections of population. However, the issue of determining and substantiating the pedagogical conditions for the training of future MMed for pedagogical activities in HMEIs did not receive an adequate coverage.

The purpose of the article - a theoretical substantiation of pedagogical conditions of training of future MMed for pedagogical activity in higher medical institutions of education.

Methodology and methods of research. The theoretical and methodological basis of the research is the analysis and generalization of legislative documents in the system of higher medical education, fundamental and modern provisions of pedagogical theory, research works of national scholars, teachers, international research in the field of health care. To achieve the goal, a set of methods and techniques of scientific knowledge have been applied. The method of logical generalization was used for theoretical substantiation of significance of the tasks set and specification of research key concepts. Using the methodology of system analysis, a study of approaches has been conducted on the selection of pedagogical conditions for the training of future MMed for teaching in HMEIs. Methods of theoretical 
generalization, grouping and comparison were used to determine the pedagogical conditions for the training of future MMed for the pedagogical activity in HMEIs.

Presenting main material. Before considering the pedagogical conditions of training of future MMed for the pedagogical activity in HMEIs, it is necessary to interpret the understanding of this concept. A condition is first and foremost a philosophical category which determines "that, from which something else, conditioned, depends on" $[3$, p.356]. That is, it is the environment, the ambience in which the phenomenon or process under study occurs, exists and develops. Understanding of many pedagogical phenomena is determined by the action of various factors, so the ability to manage such phenomena or the educational process is a successful way for creating positive conditions.

In the pedagogical encyclopedic dictionary pedagogical conditions are interpreted as the circumstances that provide efficiency of functioning of pedagogical system, success of educational process $[4$, p.201]. In the scientific literature pedagogical conditions are considered as an essential component of the educational process, which integrates a set of measures aimed at achieving this goal $[5, p .55]$. While the "set of measures" scholars interpret as external characteristics of the educational process - content, forms, methods, pedagogical techniques and means of material and spatial environment, focused on certain relationships with the inner world of a student - needs, interests, value orientations etc. [6, p.197].

For example, V. Kishchuk believes that pedagogical conditions are the result of purposeful selection, designing and application of elements of content, methods (techniques), as well as organizational forms of learning to achieve certain goals [7, p.94]. Within the article, pedagogical conditions are understood as external circumstances that significantly impact the course of the educational process, to some extent consciously constructed by a teacher, and foresee the achievement of a certain result.

Thus, W. Suh and S. Lee consider pedagogical conditions as certain circumstances that contribute in the professional training of future physicians to the development of readiness to make joint decisions with patients, and distinguish such conditions:

1) cognitive: intensification of the learning process and knowledge acquisition; ensuring the variability of the content of professional training in HMEIs in the context of future doctors' activity;

2) axiological: stimulating motivation to achieve in the training of future doctors to make joint decisions with patients; formation of students' value attitude to professionally oriented training; axiologization of knowledge in the process of practice in medicallyprophylactic institutions and the formation of values for the cognitive independence of students;

3) praxeological: modeling in the educational process of situations of independent cognitive activity in order to develop intellectual and cognitive skills: search, communicative information-analytical, creative, reflective; actualization of intersubjective relations through the implementation of individualization of the learning process and educational cooperation $[8$, p.28-31].

Empirical search, approbation at practice of separate elements of the meaningful model becomes a powerful stimulus to searches of system of optimum pedagogical means and conditions. As a rule, such a search begins at the stage of theoretical analysis, because the comprehension of experience, professional reflection is a powerful stimulus to professional self-development.
As L. Rusalkina expediently points out, the selection of effective means and conditions motivates a teacher to construct a more perfect pedagogical system, which is most often manifested in the development of various copyright programs [9].

In view of this, in order to find an effective set (system) of pedagogical conditions for the training of future MMed for pedagogical activity in HMEIs, it is necessary to: (i) identify external factors that significantly impact this process; (ii) distinguish pedagogically controlled conditions. In order to design a system of pedagogical conditions for the training of future MMed for pedagogical activities in HMEIs, it seems necessary to perform the following research procedures:

- To reveal, on the basis of the conceptual analysis of empirical pedagogical material, pedagogical scientific literature, and own pedagogical experience, the developmental potential which is placed in the chosen priority methods and forms of work with medical students;

- To identify in pedagogical practice and existing theoretical the approaches, characteristic episodes, tendencies to stimulate or counteracts of the development of the studied phenomenon;

- Select the most effective and manageable pedagogical conditions, and appropriate methods, techniques and forms of work;

- To build a pedagogically appropriate logic of their development, which ensures the maximum (step-bystep) involvement of future MMed in the educational process and the growth of their subjectivity;

- To select means of diagnostics and correction of the process, and to prove the efficiency of the offered system of pedagogical conditions and its optimality.

Based on the outlined, we assume that the pedagogical conditions reflect:

1) qualitative characteristics of the main factors, processes and phenomena of the educational environment, which reflect the basic requirements for the organization of activity;

2) a set of objective opportunities, circumstances of the educational process, purposefully created and implemented in the educational environment, providing a solution to the assigned pedagogical task;

3 ) a set of measures to increase the efficiency of the process of training of future MMed for pedagogical activities in HMEIs:

Informational - the content of education, a cognitive basis of the educational process;

- Technological - forms, means, methods, techniques, stages, ways of the organization of educational activity; procedural and methodological basis of the educational process);

- Personal (behavior, activity, communication, personal qualities of the educational process subjects);

- Psychological basis of the educational process.

At the same time, whereas conditions of the first and second subgroups (together with the essence and content of the pedagogical task) characterize actually the educational process and are a kind of "didactic cell", then the content of the third and fourth subgroups, according to A. Tulegenova, are the conditions for the effective functioning of the "didactic cell" [10]. The following conditions are to be additionally included in this subgroup:

1) determined by the personal qualities of students, in particular the peculiarities of their orientation (motivational structure of personality, value orientations, etc.);

2) determined by the personal characteristics of students (personality type, features of mental processes, 
value system, self-esteem, etc.);

3) related to interpersonal interaction and communication between a teacher and students (communication style, activity in the interaction, coincidence of learning and teaching styles, etc.).

The selection of structural components of pedagogical conditions is based on the principle of systematization, when selected components in a certain relationship and functional direction, are aimed at obtaining a systemic effect - creation of favorable conditions (increasing of efficiency) of training future MMed for teaching activity and achieving the expected result - their formation of readiness for pedagogical activity in the health care system. To substantiate the selection of specific pedagogical conditions under research structural components of the theory of solving inventive problems have been used: a system operator and vepol analysis - analysis of capabilities of the system, which covers a certain number of substances and fields (influences) in their relationship (as a model for implementing a system approach in defining and structuring of pedagogical conditions)

The analysis of researches on identifying pedagogical conditions helps to solve the educational task - training of future MMed for teaching in HMEIs and achieving the expected result - the formation of graduates' readiness for pedagogical activity in the health care system, allowed to identify such effective pedagogical conditions:

1) orientation of the educational process on the formation of motivational and value attitude of future MMed to pedagogical activity in the health care system;

2) pedagogically oriented connotation of the content and methods of studying general scientific and medical courses;
3) an optimal combination of educational forms, methods, technologies in the studying pedagogical component of medical practice by future MMed;

4) stimulating future MMed to personal and professional self-development.

In general, a theoretical study to determine the pedagogical conditions for the training of future MMed for pedagogical activity in HMEIs allowed to make the following conclusion:

- Pedagogical conditions of training of future MMed for pedagogical activity in HMEIs are the combination of the elements that provide achievement of the planned result - formation of readiness of future MMed for pedagogical activity.

- Effective pedagogical conditions for the training of future MMed for pedagogical activity in HMEIs are: (i) the orientation of the educational process on the formation of motivational and value attitude of future MMed to pedagogical activity in the health care system; (ii) pedagogically oriented connotation of the content and methods of studying general scientific and medical courses; (iii) optimal combination of educational forms, methods, technologies in the studying a pedagogical component of medical practice by future MMed; (iv) stimulating future MMed to personal and professional self-development.

- It is possible to consider the outlined issues only as a set of pedagogical conditions in their interrelation and complementarity.

The research conducted does not cover the whole problem of pedagogical activity of future MMed, does not claim to be a comprehensive consideration of the problem. The further research requires the role and importance of practical training in the formation of basics of pedagogical skills in future MMed.

\section{Список використаної літератури}

1. Бухальська С.Є. Розвиток педагогічної компетентності викладачів у системі методичної роботи медичного коледжу: дис. ... канд. пед. наук: 13.00.04. Київ, 2013. 200 с.

2. Ємець А.В. Підготовка майбутніх сімейних лікарів до застосування фізично-реабілітаційних технологій у професійній діяльності: автореф. дис. ... канд. пед. наук: 13.00.04. Запоріжжя, 2015. 22 с.

3. Філософський енциклопедичний словник: близько 2000 слів / за ред. В. Шинкарука. К.: Абрис, 2002. 742 с.

4. Гончаренко С.У. Український педагогічний енциклопедичний словник. Рівне: Волинські обереги, 2011. 519 с.

5. Гуменна I. Педагогічні умови та модель підготовки майбутніх лікарів до професійної комунікації. Педагогіка $i$ психологія професійної освіти. 2016. Вип. 1. С.53-60.

6. Остраус Ю.М. Педагогічні умови формування професійно-комунікативної культури майбутніх сімейних лікарів: дис. . канд. пед. наук: 13.00.04 / Вінницький держ. пед. ун-тет ім. М. Коцюбинського. Вінниця, 2020. 366 с.

7. Кіщук В.М. Педагогічні умови наступності професійної підготовки майбутніх фармацевтів у системі коледж-медична академія: дис. ... канд. пед. наук: 13.00.04 (015 Професійна освіта (за спеціалізаціями) / Хмельниц. нац. ун-тет; Нац. ун-тет «Львівська політехніка», Львів, 2020. 296 с.

8. Suh W., Lee C. Impact of Shared-Decision Making on Patient Satisfaction. Journal of Preventive Medicine and Public Health. 2010. Vol. 43(1). P.26-34

9. Русалкіна Л. Г. Педагогічні умови англомовної професійної підготовки майбутніх лікарів. Вісник Національної академії Державної прикордонної служби України. Серія: Педагогіка. 2018. Вип. 1. URL: https://www.onmedu.edu.ua/xmlui/ handle/123456789/3808 (дата звернення: 08.09.2021)

10.Тулегенова А.Г. Некоторые психолого-педагогические условия оптимизации учебно-воспитательного процесса. Ученые записки Симферопольского государственного университета. Серия: Экономика. География. История. Филология. 1997. Т. 3 (42). С.166-174.

\section{References}

1. Bukhal's'ka, S.Ye. (2013). Rozvytok pedahohichnoyi kompetentnosti vykladachiv u systemi metodychnoyi roboty medychnoho koledzhu [Development of pedagogical competence of teachers in the system of methodical work of medical college] [Unpublished Candidate dissertation]. Borys Hrinchenko Kyiv University. [in Ukrainian].

2. Yemets', A.V. (2015). Pidhotovka maybutnikh simeynykh likariv do zastosuvannya fizychno-reabilitatsiynykh tekhnolohiy $u$ profesiyniy diyal'nosti [Training of future family doctors for the use of physical rehabilitation technologies in professional activities] [Extended abstract of Candidate dissertation]. Zaporizhzhia Classic Private University. [in Ukrainian].

3. Shinkaruk, V. (Ed.). (2002). Filosofs'kyy entsyklopedychnyy slovnyk: blyz'ko 2000 sliv [Philosophical encyclopedic dictionary: about 2000 words]. Abrys. [in Ukrainian].

4. Honcharenko, S.U. (2011). Ukrayins'kyy pedahohichnyy entsyklopedychnyy slovnyk [Ukrainian pedagogical encyclopedic dictionary]. Volyns'ki oberehy. [in Ukrainian].

5. Humenna, I. (2016). Pedahohichni umovy ta model' pidhotovky maybutnikh likariv do profesiynoyi komunikatsiyi [Pedagogical conditions and model of preparation of future doctors for professional communication]. Pedahohika i psykholohiya profesiynoyi osvity, 1, 53-60. [in Ukrainian].

6. Ostraus, Yu.M. (2020). Pedahohichni umovy formuvannya profesiyno-komunikatyvnoyi kul'tury maybutnikh simeynykh likariv [Pedagogical conditions for the formation of professional and communicative culture of future family doctors] [Unpublished 
Candidate dissertation]. Mykhailo Kotsyubynsky Vinnytsia State Pedagogical University. [in Ukrainian].

7. Kishchuk, V.M. (2020). Pedahohichni umovy nastupnosti profesiynoyi pidhotovky maybutnikh farmatsevtiv u systemi koledzh - medychna akademiya [Pedagogical conditions of continuity of professional training of future pharmacists in the system college-medical academy] [Unpublished Candidate dissertation]. Khmelnytsky National University; National Lviv Polytechnic University. [in Ukrainian].

8. Suh, W., \& Lee, C. (2010). Impact of Shared-Decision Making on Patient Satisfaction. Journal of Preventive Medicine and Public Health, 43 (1), 26-34.

9. Rusalkina, L.H. (2018). Pedahohichni umovy anhlomovnoyi profesiynoyi pidhotovky maybutnikh likariv [Pedagogical conditions of English-language professional training of future doctors]. Visnyk Natsional'noyi akademiyi Derzhavnoyi prykordonnoyi sluzhby Ukrayiny. Seria: Pedahohika, 1, https://www.onmedu.edu.ua/xmlui/handle/123456789/3808. [in Ukrainian].

10.Tulegenova, A.G. (1997). Nekotoryye psikhologo-pedagogicheskiye usloviya optimizatsii uchebno-vospitatel'nogo protsessa [Some psychological and pedagogical conditions for the optimization of the educational process]. Uchenyye zapiski Simferopol'skogo gosudarstvennogo universiteta. Seriya: Ekonomika. Geografiya. Istoriya. Filologiya, 3 (42), 166-174. [in Russian].

Стаття надійшла до редакції 10.10.2021 р. Стаття прийнята до друку 15.10.2021 р.

Гуменюк Василь Васильович

кандидат педагогічних наук, доцент

доцент кафедри медицини катастроф та військової медицини

Львівський національний медичний університет імені Данила Галицького м. Львів, Україна

\section{ПЕДАГОГІЧНІ УМОВИ ПІДГОТОВКИ МАЙБУТНІХ МАГІСТРІВ МЕДИЦИНИ ДО ПЕДАГОГІЧНОЇ ДІЯЛЬНОСТІ У ВИЩИХ МЕДИЧНИХ ЗАКЛАДАХ ОСВІТИ}

Анотація. Підготовка майбутніх магістрів медицини до педагогічної діяльності надзвичайно актуальна.

На плечах лікарів, лежить відповідальність за життя людей, за майбутнє нації. Сучасний лікар, взаємодіючи 3 пацієнтами, з колегами, повинен займати позицію не лише медика, а й позицію вчителя, вихователя, помічника, друга, наставника. Всі ці якості допомагає сформувати і реалізувати педагогіка. Знання в галузі педагогіки допомагають лікареві ставати гідним представником професії, легко контактувати з різними людьми, одночасно виявляючи високий професіоналізм і великодушність. Мета дослідження полягає у відображенні педагогічних умов підготовки майбутніх магістрів медицини до педагогічної діяльності у вищих медичних закладах освіти. Методи дослідження: системного аналізу, логічного та теоретичного узагальнення, групування і порівняння. Встановлено, що педагогічні умови передбачають створення освітнього середовища, в якому з'являється і реалізується можливість підготовки майбутніх магістрів медицини до педагогічної діяльності у вищих медичних закладах освіти. Педагогічними умовами підготовки майбутніх магістрів медицини до педагогічної діяльності у вищих медичних закладах освіти визначено: спрямованість освітнього процесу на формування мотиваційно-ціннісного ставлення майбутніх магістрів медицини до педагогічної діяльності в системі охорони здоров'я; педагогічно зорієнтована конотація змісту і способів вивчення загальнонаукових і медичних дисциплін; оптимальне поєднання освітніх форм, методів, технологій в освоєнні майбутніми магістрами медицини педагогічного складника медичної практики; стимулювання майбутніх магістрів медицини до особистісного та професійного саморозвитку.

Ключові слова: вищі медичні заклади освіти; майбутні магістри медицини; педагогічна діяльність в охороні здоров'я; педагогічні умови; система професійної підготовки. 